\title{
Lesion Patterns on Early Diffusion-weighted Magnetic Resonance Imaging and Ischemic Stroke Subtypes
}

\author{
Erken Dönem Difüzyon A ğırlıklı Manyetik Rezonans Görüntülemede Lezyon Özellikleri \\ ve İskemik İnme Alt Tipleri
}

\author{
(1) Güven Ayaz1, (ㅇ Babürhan Güldiken², (1) Sezgin Kehaya², (1) Özer Aynac13 \\ 1Ezine State Hospital, Clinic of Neurology, Canakkale, Turkey \\ 2Trakya University Faculty of Medicine, Department of Neurology, Edirne, Turkey \\ 3Edirne State Hospital, Clinic of Neurology, Edirne, Turkey
}

\begin{abstract}
Objective: The correct and rapid classification of the ischemic stroke subtype enables the determination of the proper treatment and a better prognosis. In this study, we investigated the association of ischemic stroke subtypes with early diffusion-weighted magnetic resonance imaging (MRI) lesion patterns.

Materials and Methods: Three hundred forty-three consecutive patients with acute ischemic stroke were retrospectively evaluated. The ischemic stroke subtype for each patient was determined according to "Trial of Org 10172 in Acute Stroke Treatment Classification". The lesion patterns in diffusion-weighted MRI in the first 24 hours of stroke were classified as single lesions, diffuse scattered lesions limited to one vascular area, and multiple territory lesions. The relationship between the diffusion-weighted MRI lesion patterns and ischemic stroke subtypes was investigated using the chi-square test.

Results: The diffusion-weighted MRI lesion patterns showed significant differences among the ischemic stroke subtypes. Multiple territory lesions were more frequent in the cardioembolic and other determined causes groups compared with the large artery atherosclerosis group. Diffuse scattered lesions limited to one vascular area were more frequent in the large artery atherosclerosis, the unknown cause and the other determined causes groups than the others ( $<<0.01)$. Single lesions with a diameter smaller than $1.5 \mathrm{~cm}$ favored small vessel disease. None of the diffusion-weighted MRI lesion patterns was highly specific for any stroke subtype.

Conclusion: Early diffusion-weighted MRI lesion distributions vary significantly among the ischemic stroke subtypes. When evaluated with other clinical findings, these data can help in the early determination of the ischemic stroke etiology.
\end{abstract}

Keywords: Ischemic stroke, diffusion-weighted magnetic resonance imaging, atherosclerosis, cardioembolism, lacunar infarction

Öz

Amaç: Akut iskemik inmelerde inme sebebinin hızlı bir şekilde belirlenmesi tedaviyi ve sonucu olumlu etkiler. Biz bu çalışmamızda akut iskemik inme ile başvuran hastalarda ilk 24 saat içinde yapılan difüzyon ağırlıklı manyetik rezonans görüntülemede (MRG) lezyon özelliklerinin inme alt tipleri ile ilişkisini araştırdık.

Gereç ve Yöntem: Çalışmada akut iskemik inme tanısı almış ardışık 343 hasta retrospektif olarak değerlendirildi. Hastalarda "Trial of Org 10172 in Acute Stroke Treatment" sınıflama sistemine göre iskemik inme alt tipleri belirlendi. Difüzyon ağırlıklı MRG'de iskemi ile uyumlu lezyonlar tek lezyon, bir vasküler alanda multipl ve birden fazla vasküler alanda multipl lezyon olarak üçe ayrıldı. Lezyonlar daha sonra boyut ve ön arka sistemde yerleşimlerine göre tekrar 12 alt gruba ayrıldı. Belirlenen iskemik inme alt tipleri ile difüzyon ă̆ırlıklı MRG lezyon özellikleri arasındaki ilişkiler ki-kare testi ile araştırıldı.

Bulgular: Difüzyon ağırlıklı MRG lezyonlarının dağılımları inme alt tipleri arasında anlamlı farklılık gösterdi (p<0,001). Kardiyoembolik ve diğer belirlenen sebepler grubunda multipl vasküler alan lezyonları büyük arter aterosklerozundan daha sık izlendi. Tek vasküler alanda difüz dağınık lezyonlar büyük arter aterosklerozu, sebebi belirlenemeyen ve diğer belirlenen sebeplerde diğer gruplardan daha sık izlendi $(\mathrm{p}<0,001)$. Lezyonun tek ve $1,5 \mathrm{~cm}$ 'den küçük olması küçük damar hastalığı lehine bulundu. Hiç bir difüzyon ă̆ırlıklı MRG lezyon özelliği iskemik inme alt tipi için spesifik bulunmadı.

Sonuç: Erken dönem difüzyon ağırlıklı MRG’de lezyon dağılımları iskemik inme alt gruplarına göre anlamlı farklılık göstermektedir. Bu verilerin diğer klinik bulgularla birlikte değerlendirildiğinde iskemi etiyolojisi ve mekanizmasının erken dönemde saptanmasında yol gösterici olacă̆ düşünülmektedir.

Anahtar Kelimeler: İskemik inme, difüzyon ağırlıklı manyetik rezonans görüntüleme, ateroskleroz, kardiyoembolizm, laküner infarkt

Address for Correspondence/Yazışma Adresi: Sezgin Kehaya MD, Trakya University Faculty of Medicine, Department of Neurology, Edirne, Turkey Phone: +90 2842357642 E-mail: sezginkehaya@yahoo.com ORCID: orcid.org/0000-0002-9608-9278

Received/Geliş Tarihi: 05.07.2019 Accepted/Kabul Tarihi: 01.10.2019

The study was conducted from the neurology speciality thesis of Güven AYAZ. Our study was presented as a poster on May 26-28, 2017 at the 7th Ali Özeren School of Cerebrovascular Diseases (with the number P-067).

${ }^{\circ}$ Copyright 2020 by Turkish Neurological Society

Turkish Journal of Neurology published by Galenos Publishing House. 


\section{Introduction}

The proper and early treatment of acute ischemic stroke can reduce the stroke recurrence and decrease the disability. The choice of the drug therapy is made according to stroke etiology, and the Trial of Org 10172 in Acute Stroke Treatment (TOAST) criteria are currently the most used criteria that classify the etiology and stroke subtypes as large artery atherosclerosis (LAA), small vessel disease (SVD), cardioembolism (CE), unknown (UC), and other determining causes (OC) (1). Several investigations such as echocardiography, carotid artery ultrasonography, cerebral angiography are necessary for the TOAST classification, but their completion usually takes time, especially in patients whose clinical state is poor and does not allow these procedures. Due to the delay of investigations, the consistency of TOAST evaluations, which were performed on the first day and at the end of the third month of stroke, was as low as $62 \%$ (2). To increase the accuracy of TOAST classification in the first days of stoke, additional diagnostic methods seem to be necessary.

Cranial computed tomography (CT) usually fails to demonstrate infarcts in the first 24 hours of stroke and misses lacunar infarcts. The sequences of magnetic resonance imaging (MRI) other than diffusion-weighted imaging (DWI) are also not able to reveal lesions in the first hours of ischemic attack and to differentiate acute lesions from chronic lesions. On the other side, DWI-MRI can show acute ischemic lesions in the first hours of stroke (3). However, it is not infrequent that the DWI-MRI reveals lesions with various sizes, shapes, and distribution, inconsistent with the neurologic deficit of patients (4). It is not understood if the distribution and morphology of lesions are related to the stroke etiology and may be a clue for the rapid determination of the stroke subtype. Previously, several studies reported that some of the DWI-MRI lesion patterns are more frequently seen in some stroke subtypes $(5,6)$. In this study, we investigated the association of early DWI-MRI lesion characteristics with the ischemic stroke subtypes.

\section{Materials and Methods}

Three hundred forty-three patients who were admitted to the emergency department due to an acute ischemic stroke were retrospectively investigated. Patients with cerebral venous thrombosis and transient ischemic attacks were excluded from the study. Age, sex, hypertension, diabetes, ischemic stroke, coronary artery disease, hyperlipidemia, cardiac insufficiency, alcohol and cigarette use, obesity, migraine, oral contraceptive use were recorded for every patient. The information about atrial fibrillation or other rhythm disorders on electrocardiography, the lesion size and location in computed brain tomography, T2 fluid-attenuated inversion recovery MRI, the degree of carotid and major cerebral artery stenosis in Doppler ultrasonography and MR angiography, echocardiography findings, systolic and diastolic blood pressures, history or findings of coronary artery disease and congestive heart failure, blood glucose and cholesterol levels were collected from the records. DWI-MRI findings were not used in the classification of the stroke subtype.

Patients were classified as LAA if significant $(>50 \%)$ stenosis or occlusion of a major artery due to atherosclerosis was found, and if there was no potential cardioembolic source. Patients who had an intermediate or high cardiac emboli risk and no other possible stroke source were classified as cardioembolic stroke. The SVD group comprised patients with at least one traditional clinical lacunar syndrome and normal CT examinations or subcortical ischemic lesions $<1.5 \mathrm{~cm}$. The SVD group had no evidence of cerebral cortical dysfunction and no cardiac source of emboli. Patients with a rare stroke etiology, such as non-atherosclerotic vasculopathy, hypercoagulopathy and hematologic disorders were included in the OC subtype. Patients with multiple etiologic reasons or no etiologic reason despite advanced investigations were classified as UC (1).

1.5 Tesla DWI-MRI was performed in the first 24 hours of acute stroke. DWI-MRI lesions were marked for each patient on a schematic brain map. Lesion characteristics were classified into three main groups as single lesions in vascular areas (Figure $1 \mathrm{~A}$, B, C, D, E), diffuse scattered lesions limited to one vascular area (Figure $1 \mathrm{~F}, \mathrm{G}, \mathrm{H}$ ), and multiple territory lesions (Figure $1 \mathrm{I}, \mathrm{J}$, $\mathrm{K}, \mathrm{L}$ ). These three main groups were further subdivided into 12 subgroups according to their lesion size and location (Figure 1).

The study was approved by the Trakya University Noninterventional Ethics Committee (decision number: 05/04, date: 08.02.2012).
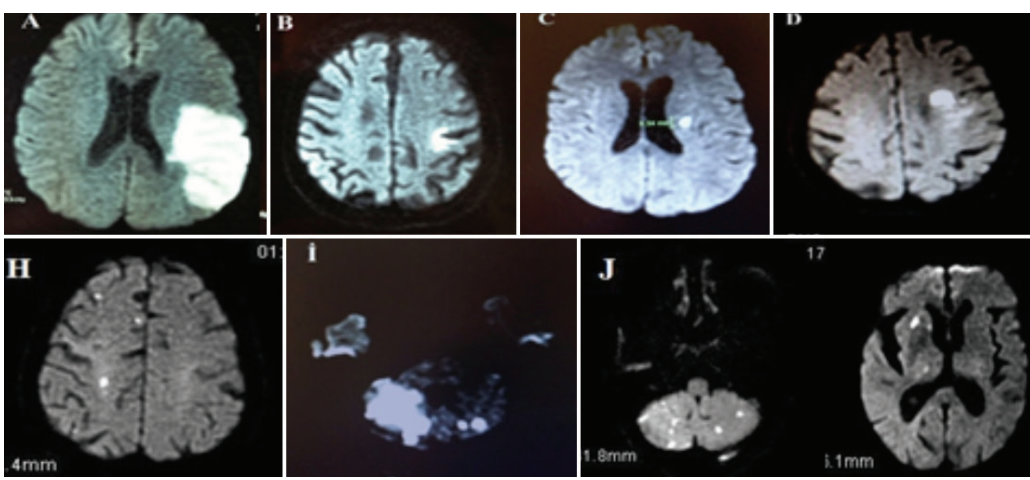
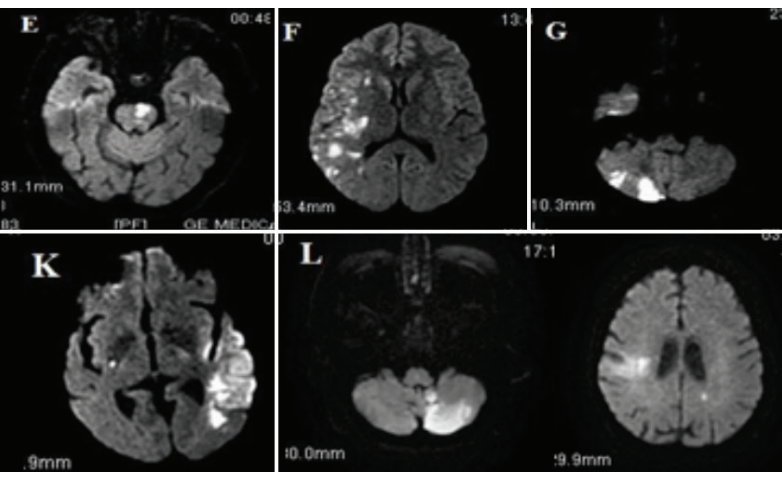

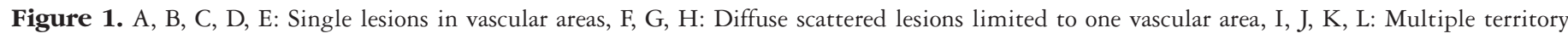

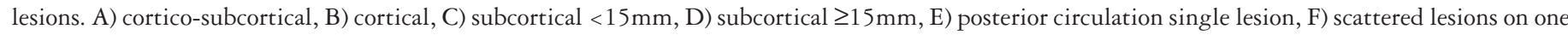

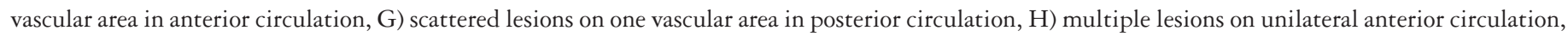

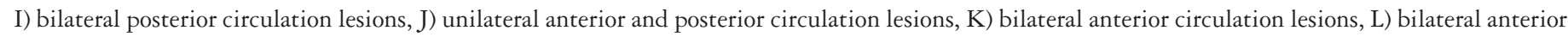
and posterior circulation lesions 


\section{Statistical Analysis}

Statistical analyses were conducted using the SPSS 20 statistical program (license number 102406421). The results are given as mean \pm standard deviation or number $(\%)$. The distribution of risk factors in stroke subgroups was analyzed using One-way ANOVA. One DWI-MRI lesion patterns and stroke subtypes were identified for each patient. Relationships between three DWIMRI patterns and five stroke subtypes were assessed using the chisquare test. Statistical significance was considered if the $\mathrm{p}$ value was less than 0.05 . The association between stroke subtypes and the subdivisions of lesion patterns were not evaluated because of the low count number.

\section{Results}

The clinical characteristics and laboratory values of the 343 patients are shown in Table 1 . One hundred thirty-nine patients (40.5\%) had LAA, 132 (38.5\%) had CE, 46 (13.4\%) had SVD, $13(3.8 \%)$ had OC, and the remaining $13(3.8 \%)$ had UC. Two hundred $(58.3 \%)$ patients had a stroke-related ischemic change in
CT imaging, and the CT of 143 patients was normal. The groups in which the CT was most commonly negative were the SVD and OC groups.

On DWI-MRI, single lesions in vascular areas were detected in 177 patients $(51.6 \%)$, diffuse scattered lesions limited to one vascular area were found in 106 patients $(30.9 \%)$, and multiple territory lesions were found in 60 patients $(17.5 \%)$. These three main types of lesions showed a statistically significant difference between stroke subtypes $(\mathrm{p}<0.001)$. Diffuse scattered lesions limited to one vascular area were found more frequently in LAA, $\mathrm{UC}$, and $\mathrm{OC}$ than in the CE and SVD groups $(\mathrm{p}<0.01)$. Multiple territory lesions were found higher in $\mathrm{CE}$ and $\mathrm{OC}$ groups than LAA $(\mathrm{p}<0.01)$. There was a high rate of single lesions in the SVD group compared with the LAA and OC groups $(p<0.01)$. The distribution of lesions was not different between the CE and SVD groups (Table 2 ).

The further distribution of lesion subgroups on DWI-MRI according to stroke subtypes is shown in Table 3. Subcortical lesions, which were smaller than $15 \mathrm{~mm}$ in diameter, were more common in the SVD group than in the others. The single

Table 1. Demographic and clinical properties of stroke subtypes

\begin{tabular}{|c|c|c|c|c|c|c|}
\hline & $\begin{array}{l}\text { LAA } \\
(n=139)\end{array}$ & $\begin{array}{l}\text { CE } \\
(n=132)\end{array}$ & $\begin{array}{l}\text { SVD } \\
(n=46)\end{array}$ & $\begin{array}{l}\text { OC } \\
(n=13)\end{array}$ & $\begin{array}{l}\text { UC } \\
(n=13)\end{array}$ & $\mathrm{p}^{*}$ \\
\hline Age-years & $65.65 \pm 1.15$ & $72.14 \pm 11.35$ & $64.76 \pm 13.53$ & $65.92 \pm 20.03$ & $69.75 \pm 9.85$ & $<0.001$ \\
\hline $\operatorname{Sex}(m / f)$ & $85 / 54$ & $53 / 79$ & $33 / 13$ & $7 / 6$ & $3 / 10$ & $<0.001$ \\
\hline Hypertension n (\%) & $102(73.4 \%)$ & $112(84.8 \%)$ & $31(67.4 \%)$ & $11(84.4 \%)$ & $12(92.3 \%)$ & 0.05 \\
\hline DM n (\%) & $59(42.4 \%)$ & $38(28.8 \%)$ & $14(30.4 \%)$ & $3(23.1 \%)$ & $4(30.8 \%)$ & NS \\
\hline Previous Stroke n (\%) & $42(30.2 \%)$ & $53(40.2 \%)$ & $11(23.9 \%)$ & $5(38.5 \%)$ & $6(46.2 \%)$ & NS \\
\hline Smoking & $38(27.3 \%)$ & $15(11.4 \%)$ & $13(28.3 \%)$ & $5(38.5 \%)$ & $1(7.7 \%)$ & 0.01 \\
\hline CAD n (\%) & $15(10.8 \%)$ & $49(37.1 \%)$ & $6(13 \%)$ & $3(23.1 \%)$ & $3(23.1 \%)$ & $<0.001$ \\
\hline HL n (\%) & $43(30.9 \%)$ & $36(27.3 \%)$ & $14(30.4 \%)$ & $4(30.8 \%)$ & $0(0 \%)$ & NS \\
\hline CHF n (\%) & $10(7.2 \%)$ & $50(37.9 \%)$ & $2(4.3 \%)$ & $5(38.5 \%)$ & $2(15.4 \%)$ & $<0.001$ \\
\hline Systolic BP (mm Hg) & $136.22 \pm 15.74$ & $154.7 \pm 22.29$ & $140.87 \pm 20.52$ & $147.69 \pm 19.64$ & $169.23 \pm 18.46$ & $<0.001$ \\
\hline Blood sugar (mg/dl) & $79.78 \pm 10.24$ & $90.53 \pm 12.92$ & $83.04 \pm 13.96$ & $88.46 \pm 11.43$ & $82.31 \pm 13.01$ & 0.01 \\
\hline LDL-C (mg/dl) & $130.99 \pm 36.22$ & $115.72 \pm 39.30$ & $129.89 \pm 41.35$ & $117.46 \pm 38.65$ & $116.25 \pm 42.65$ & 0.01 \\
\hline CT lesion + n (\%) & $90(64.7)$ & $80(60.6)$ & $18(39.1)$ & $5(38.5)$ & $7(53.8)$ & 0.01 \\
\hline
\end{tabular}

Table 2. Association of diffusion-weighted imaging-magnetic resonance imaging lesion patterns with stroke subtypes

$\begin{array}{llll}\begin{array}{l}\text { Single lesion in vascular areas, } \\ \mathbf{n}\end{array} & \begin{array}{l}\text { Scattered lesions in one } \\ \text { vascular area, } \mathbf{n}\end{array} & \begin{array}{l}\text { Multiple lesions in } \\ \text { multiple vascular areas, } \mathbf{n}\end{array} & \begin{array}{c}\text { Total, } \mathbf{n}(100 \%) \\ 69(49.6 \%) \mathrm{c}\end{array} \\ 55(39.6 \%)^{\mathrm{ab}} & 15(10.8 \%) & 139 \\ 68(51.5 \%)^{\mathrm{d}} & 33(25.0 \%) & 31(23.5 \%)^{\mathrm{a}} & 129 \\ 32(69.6 \%)^{\mathrm{b}} & 7(15.2 \%) \mathrm{e} & 7(15.2 \%) & 46 \\ 2(15.4 \%) & 6(46.2 \%) & 5(38.5 \%)^{\mathrm{c}} & 13 \\ 6(46.1 \%) & 5(38.5 \%) & 2(15.4 \%) & 13 \\ 177(51.6 \%) & 106(30.9 \%) & 60(17.5 \%) & 343 \\ & & \end{array}$


corticosubcortical lesions were more frequent in CE and UC groups.

\section{Discussion}

In our study, we found that DWI-MRI lesion characteristics differed among the ischemic stroke types. Scattered lesions in one vascular territory were more common in LAA, OC, and UC, whereas multiple territory lesions were more frequent in the $\mathrm{CE}$ and OC subgroups. We consider that DW-MRI lesion feature patterns may assist in the diagnosis of the stroke etiology before the meticulous examination of patients such as the imaging of cerebral angiography and echocardiography is completed. However, we also saw that none of DWI-MRI findings were specific for a stroke subtype. Three different DWI-MRI lesion patterns could appear at different ratios in each stroke subtype, so it was not possible to accurately diagnose the subtype of stroke solely depending on the lesion pattern on DWI-MRI.

Lee et al. (7) showed that the stroke classification accuracy with TOAST criteria could be increased from $56 \%$ to $94 \%$ with DWI-MRI. They described the stroke subtype in the first 24 hours of stroke using TOAST criteria with and without DWI-MRI technique and finally compared it with that at the discharge of patient after the completion of other necessary investigations. For the TOAST diagnostic subtypes of large-vessel atherothrombosis and small-vessel disease, pre-DWI-MRI diagnoses matched final diagnoses in $56 \%$ and $35 \%$ of patients, respectively, improving to $89 \%$ and $100 \%$ after DWI/MR Angiography. DWI of infarct topography was claimed to assist subtype diagnosis in several ways, including (1) distinguishing when classic lacunar syndromes were indeed due to small, deep infarcts $1.5 \mathrm{~cm}$ in diameter versus larger territorial infarcts; (2) in conversely determining when non-classic lacunar clinical syndromes were due to small, deep infarcts rather than to larger insults; (3) indicating multiple acute lesions in more than one vascular territory in patients with only one symptomatic lesion, which is consistent with CE; and (4) determining acute, symptomatic lesions from several chronic deep and cortical lesions (7).

Multiple territory lesions on DWI-MRI are an expected finding in CE $(8,9,10)$. Cardiac emboli material can multiply at the time of embolism and may have been led to different vascular areas. However, multiple territory lesions were also seen in $10.8 \%$ of patients with LAA in our study. This can be explained by the variation of vessels such as the feeding of two arterial territories from one artery. It was shown that the fetal posterior cerebral arteries originating from carotid artery or patent posterior communicating artery can be observed in $67 \%$ of cases and patent posterior choroidal arteries in $25 \%$ of cases, which can cause anterior and posterior circulation lesions simultaneously. Also, $18 \%$ of the anterior cerebral arteries can originate from a single carotid artery $(3,9,10,11)$. The multiple territory lesions in the OC group are probably because this group mainly involves hematologic and vasculitic rheumatic diseases, which affect all vascular areas at the same time $(6,9,10,12)$. Cancer, septic emboli, and hypercoagulopathy were reported as other potential causes of multiple territory lesions (13).

We detected diffuse scattered lesions in one vascular area in the LAA group at a higher rate. Our result was concordant with previous studies $(6,8,11,14,15)$. The presence of either "string of pearls" or "scattered pearls" on MRI was found to be associated with an independently determined mechanism of intracranial or extracranial arterial stenosis $(16,17)$. The incomplete fibrinolysis of the embolic thrombus that comes from an atheromatous plaque of a large artery and hypoperfusion might be explanations for the mechanism of the scattered lesions in $\operatorname{LAA}(9,18)$.

A single lesion smaller than $15 \mathrm{~mm}$ and a concomitant lacunar syndrome is specific for SVD (1). In our study, both diffuse scattered lesions in one vascular area and multiple territory lesions were also found in a small ratio of patients with SVD (both, $15.2 \%)$. Presumably, one of these multiple lesions gives rise to clinical lacunar syndrome, whereas the others affect silent areas. It

\begin{tabular}{|c|c|c|c|c|c|c|}
\hline & $\begin{array}{l}\text { LAA } \\
\text { n (\%) }\end{array}$ & $\begin{array}{l}\text { CE } \\
\text { n }(\%)\end{array}$ & $\begin{array}{l}\text { SVD } \\
\text { n }(\%)\end{array}$ & $\begin{array}{l}\text { OC } \\
\text { n }(\%)\end{array}$ & $\begin{array}{l}\mathrm{UC} \\
\mathrm{n}(\%)\end{array}$ & $\begin{array}{l}\text { Total } \\
\mathrm{n}\end{array}$ \\
\hline Single corticosubcortical & $23(15.5)$ & $29(21.9)$ & 0 & $1(7.6)$ & $4(30.7)$ & 57 \\
\hline Single cortical & $1(0.7)$ & $10(7.5)$ & $2(4.3)$ & 0 & 0 & 13 \\
\hline Single subcortical $\geq 15 \mathrm{~mm}$ & $7(5)$ & $13(9.8)$ & $3(6.5)$ & 0 & 0 & 23 \\
\hline Single subcortical $<15 \mathrm{~mm}$ & $13(9.3)$ & $7(5.3)$ & $20(43.4)$ & 0 & $1(7.6)$ & 41 \\
\hline Single post. circulation & $25(17.9)$ & $9(6.8)$ & $7(15.2)$ & $1(7.6)$ & $1(7.6)$ & 43 \\
\hline SOVA ant. circulation & $42(30.2)$ & $26(19.6)$ & $5(10.6)$ & $6(46.1)$ & $5(38.4)$ & 84 \\
\hline SOVA post. circulation & $13(9.3)$ & $7(5.3)$ & $2(4.3)$ & 0 & 0 & 22 \\
\hline MTL unilat. ant. circulation & $1(0.7)$ & 0 & 0 & 0 & 0 & 1 \\
\hline MTL post. circulation & $1(0.7)$ & $3(2.2)$ & $2(4.3)$ & 0 & 0 & 6 \\
\hline MTL unilat. ant. and post. circulation & $2(1.4)$ & $7(5.3)$ & $3(6.5)$ & $3(23)$ & $1(7.6)$ & 16 \\
\hline MTL bilat. ant. circulation & $10(7.2)$ & $10(7.5)$ & $1(2.8)$ & $1(7.6)$ & 0 & 22 \\
\hline MTL bilat. ant. and post. circulation & $1(0.7)$ & $11(8.3)$ & $1(2.8)$ & $1(7.6)$ & $1(7.6)$ & 15 \\
\hline Total n (\%) & $139(100)$ & $132(100)$ & $46(100)$ & $13(100)$ & $13(100)$ & 343 \\
\hline
\end{tabular}


may be more appropriate to redefine the patients with SVD with multiple lesions on DWI-MRI as UC. Previous studies similarly reported non-lacunar infarcts in SVD (19,20). Arboix et al. (20) studied patients with lacunar syndrome and reported non-lacunar infarcts in $16.6 \%$ of patients with lacunar syndrome (20). Atrial fibrillation was detected in $30 \%$ of patients with lacunar syndrome and non-lacunar infarction, whereas this rate was $11 \%$ in patients with lacunar syndrome with lacunar infarction.

In the subanalysis of DWI-MRI lesions (Table 3), we observed that single corticosubcortical lesions were more common in CE and UC. Likewise, Yamamoto et al. (6) found corticosubcortical infarcts more frequent in patients with CE than thse with LAA. The explanation might be that cardiac thrombi are relatively large fibrin-rich large thrombi and obstruct mainly large arteries, but thrombi from large arteries are thrombocyte-rich and slightly smaller thrombi that can pass into the distant small arteries of the brain $(11,18)$.

\section{Conclusion}

The retrospective nature of our study and the low number of patients in diffusion-weighted MR subgroups are the limiting aspects of our study. As a result, we emphasize that none of the DWI-MRI lesion patterns are specific for any type of stroke etiology. However, the diffuse scattered lesions in vascular territories were more common in LAA, OC, and UC than the other subtypes, and multiple territory lesions were more common in CE and OC. Careful evaluation of DWI-MRI findings in combination with other clinical features may help in the early determination of ischemic etiology and mechanism.

\section{Ethics}

Ethics Committee Approval: The study was approved by the Trakya University Non-interventional Ethics Committee (decision number: 05/04, date: 08.02.2012).

Informed Consent: Because of retrospective nature of the study, no informed consent had been obtained from the patients.

Peer-review: Externally peer-reviewed.

\section{Authorship Contributions}

Concept: B.G., Design: B.G.,G.A., Data Collection or Processing: G.A., S.K., Ö.A., Analysis or Interpretation: B.G., S.K., Literature Search: B.G., S.K., Ö.A., Writing: B.G., S.K.

Conflict of Interest: No conflict of interest was declared by the authors.

Financial Disclosure: The authors declared that this study received no financial support.

\section{References}

1. Adams HP, Bendixen BH, Kappelle LJ et al. Classification of subtype of acute ischemic stroke. Definitions for use in a multicenter clinical trial. TOAST. Trial of Org 10172 in Acute Stroke Treatment. Stroke 1993;24:3541.
2. Madden KP, Karanjia PN, Adams HP, Clarke WR. Accuracy of initial stroke subtype diagnosis in the TOAST study. Neurology 1995;45:1975-1979.

3. Warach S, Gaa J, Siewert B, Wielopolski P, Edelman RR. Acute human stroke studied by whole brain echo planar diffusion-weighted magnetic resonance imaging. Ann Neurol 1995;37:231-241.

4. Baird AE, Lovblad KO, Dashe JF, et al. Clinical correlations of diffusion and perfusion lesion volumes in acute ischemic stroke. Cerebrovasc Dis 2000;10:441-448.

5. Kvistad CE, Oygarden H, Logallo N, et al. A dark side of subcortical diffusion-weighted lesions? Characteristics, cause, and outcome in large subcortical infarction: the bergen norwegian stroke cooperation study. Stroke 2014;45:2710-2716.

6. Yamamoto N, Satomi J, Yamamoto Y, et al. The susceptibility vessel sign containing two compositions on 3-tesla T2*-weighted image and single corticosubcortical infarct on diffusion-weighted image are associated with cardioembolic stroke. J Neurol Sci 2015;359:141-145.

7. Lee LJ, Kidwell CS, Alger J, Starkman S, Saver JL. Impact on stroke subtype diagnosis of early diffusion-weighted magnetic resonance imaging and magnetic resonance angiography. Stroke 2000;31:1081-1089.

8. Kang DW, Chalela JA, Ezzeddine MA, Warach S. Association of ischemic lesion patterns on early diffusion-weighted imaging with TOAST stroke subtypes. Arch Neurol 2003;60:1730-1734.

9. Rovira A, Grive E, Sabin JA. Distribution territories and causative mechanisms of ischemic stroke. Eur Radiol 2005;15:416-426.

10. Kang DW, Chu K, Ko SB, et al. Lesion patterns and mechanism of ischemia in internal carotid artery disease: a diffusionweighted imaging study. Arch Neurol 2002;59:1577-1582.

11. Lee KJ, Jung KH, Byun JI, Kim JM, Roh JK. Infarct pattern and clinical outcome in acute ischemic stroke following middle cerebral artery occlusion. Cerebrovasc Dis 2014;38:31-38.

12. Depuydt S, Sarov M, Vandendries C, et al. Significance of acute multiple infarcts in multiple cerebral circulations on initial diffusion weighted imaging in stroke patients. J Neurol Sci 2014;337:151-155.

13. Schwarzbach CJ, Fatar M, Eisele P, et al. DWI lesion patterns in cancerrelated stroke-specifying the phenotype. Cerebrovasc Dis Extra 2015;5:139145 .

14. Chung JW, Park SH, Kim N, et al. Trial of ORG 10172 in Acute Stroke Treatment (TOAST) classification and vascular territory of ischemic stroke lesions diagnosed by diffusion-weighted imaging. J Am Heart Assoc 2014;3:e001119.

15. Oyama N, Moriwaki H, Yamada N, Nagatsuka K, Naritomi H. Estimation of stroke etiology from lesion patterns on diffusion-weighted magnetic resonance imaging in patients with carotid artery occlusive disease. Eur Neurol 2012;69:142-148.

16. Turtzo LC, Gottesman RF, Llinas RH. Diffusion-weighted imaging showing 'pearls' predicts large-vessel disease as stroke etiology. Cerebrovasc Dis 2009;28:49-54.

17. Deb P, Sharma S, Hassan KM. Pathophysiologic mechanisms of acute ischemic stroke: an overview with emphasis on therapeutic significance beyond thrombolysis. Pathophysiology 2010;17:197-218.

18. Kim JS, Nah HW, Park SM, et al. Risk factors and stroke mechanisms in atherosclerotic stroke intracranial compared with extracranial and anterior compared with posterior circulation disease. Stroke 2012;43:3313-3318.

19. Naess H, Brogger JC, Idicula T, et al. Clinical presentation and diffusion weighted MRI of acute cerebral infarction. The Bergen Stroke Study. BMC Neurol 2009;9:44.

20. Arboix A, Massons J, García-Eroles L, et al. Clinical predictors of lacunar syndrome not due to lacunar infarction. BMC Neurol 2010;10:31. 